\title{
Effect of Calcarisporium arbuscula on adventitious root development and peroxidase activity in two elepidote rhododendron cultivars
}

\author{
Kristine Dokane ${ }^{1,2 *}$, Dace Megre ${ }^{1,3}$, Lelde Stirna ${ }^{1,4}$, Karlis Dumins $^{1,5}$, Uldis Kondratovics ${ }^{1,6}$ \\ ${ }^{1}$ Faculty of Biology, University of Latvia, Jelgavas 1, Riga LV-1004, Latvia \\ ${ }^{2}$ Institute of Biology, University of Latvia, Miera 3., Salaspils LV-2169, Latvia \\ ${ }^{3}$ Department of Plant Ecophysiology, National Botanical Garden, Miera 1, Salaspils, LV-2169, Latvia \\ ${ }^{4}$ Latvian Plant Protection Research Centre, Struktoru 14A., Riga LV-1039 Latvia \\ ${ }^{5}$ Latvian State Forest Research Institute "Silava”, Rīgas 111, Salaspils, LV-2169 Latvia \\ ${ }^{6}$ Botanical Garden, University of Latvia, Kandavas 2, Riga LV-1083, Latvia \\ ${ }^{*}$ Corresponding author, E-mail: kristine.dokane@lu.lv
}

\begin{abstract}
Effect of Calcarisporium arbuscula on adventitious root development in leaf-bud cuttings of two elepidote rhododendron cultivars was studied. Guaiacol peroxidase activity was determined and anatomical study was performed in untreated cuttings (control), and cuttings treated with $1 \%$ indole-3-butyric acid (IBA) or C. arbuscula. In rhododendron cv. 'Babìtes Lavanda' both IBA and C. arbuscula treatment slightly delayed adventitious root formation; the overall rooting percentage remained high ( 94 and $92 \%$, respectively) but lower than in the control (96\%). IBA and C. arbuscula treatments had a strongly positive effect on long term survival of rooted cuttings (73 and $70 \%)$ compared to the control (54\%). There was no difference in peroxidase activity between the treatments. In rhododendron cv. 'Nova Zembla', IBA and C. arbuscula treatments promoted formation of adventitious root initials and primordia as well as strongly increased rooting percentage (63 and 70\%) compared to the control (38\%). In addition, peroxidase activity was significantly higher in C. arbuscula treated cuttings during the whole experiment.
\end{abstract}

Key words: anatomy, fungal endophyte, leaf-bud cuttings, rhizogenesis.

Abbreviations: IBA, indole-3-butyric acid.

\section{Introduction}

Rhododendrons as ornamental plants are well known for their wide diversity of habitual characteristics, which allows the use of these decorative plants in many botanical gardens, city parks as well as private gardens (Ferus et al. 2017). Propagation by stem cuttings is the most popular method for rhododendron propagation (Wells 1982). However, in comparison, propagation by leaf-bud cuttings is a more productive method as higher amounts of young plants can be produced from less stock plant material. An essential process during plant propagation by cuttings is adventitious root formation (Hartmann et al. 2014). Many studies have been aimed on application of endophytic or mycorrhizal fungi on plant material during the propagation in order to increase plant biomass, stress resistance related traits or chemical compound production in plants (Mucciarelli et al. 2003, Scagel 2005; Ávila Díaz-Granados et al. 2009; Bizabani, Dames 2015). Such treatment has also been performed during micropropagation (Mucciarelli et al. 2003; Fusconi et al.2010). The studies using conventional propagation techniques are mostly performed with seeds and aimed to increase morphogenic potential or stress resistance-related traits (Yang et al. 2014; Grelet et al. 2017); however, often underlying biochemical or physiological mechanisms are not studied.

Several studies have shown a positive effect of fungal endophytes on different plant traits both in woody and herbaceous plants during vegetative propagation. The fungal endophyte PGP-HSF has a positive effect on growth and shoot and root biomass of in vitro cultured Mentha piperita (Mucciarelli et al. 2003, Fusconi et al. 2010). Lachnum and Cadophora isolates have a cultivar dependent positive or neutral effect on micropropagated Vaccinium corymbosum shoot and root biomass ex vitro (Bizabani, Dames 2015). Previously we have shown a positive effect of Calcarisporium arbuscula Preuss on in vitro growth, pigment content and ex vitro rooting of microshoots of elepidote rhododendron cultivars 'Babites Lavanda' and 'Nova Zembla' (Dokane et al. 2017). In vitro grown rhododendron material is anatomically very heterogeneous and besides the different exogenous treatments, further rooting may be influenced by developmental stages of vascular cylinder and by phloem to xylem ratio of 
microshoots (Dokane et al. 2014). Thus, considering the higher anatomical homogeneity of plant material used in conventional propagation techniques, we decided to clarify the effect of $C$. arbuscula on adventitious root formation in rhododendron leaf-bud cuttings using the same two cultivars previously used in our ex vitro rooting experiment (Dokane et al. 2017).

Many studies have been performed to understand anatomical, physiological and biochemical processes during adventitious root formation and it is considered that adventitious rooting anatomically and biochemically consists of three subsequent phases: induction, initiation and expression (Gaspar et al. 1994; Husen 2008; Naija et al. 2008). In several plant species, including rhododendrons, changes in peroxidase activity have been suggested as a biochemical marker for these phases (Metaxas et al. 2004; Syros et al. 2004, Naija et al. 2008; Megre et al. 2011). Thus, study of these phases allows understanding the role of different rooting promoting treatments on biochemical course of the adventitious root formation. Previously we showed a correlation between peroxidase activity in leaves and bases of rhododendron leaf-bud cuttings, which allows to perform simultaneous anatomical study and peroxidase activity assay on the same plant material (Megre et al.2011). Thus, in current study rhododendron leaves were used for peroxidase activity assay.

The aim of the study was to clarify the effect of $C$. arbuscula on adventitious rooting of leaf-bud cuttings of two elepidote rhododendron cultivars, 'Babìtes Lavanda' and 'Nova Zembla'.

\section{Materials and methods}

\section{Fungal culture and spore suspension preparation}

Calcarisporium arbuscula was previously isolated from roots of a 3-year-old elepidote rhododendron 'Babites Lavanda' plant (Dokane et al.2012) and preserved in culture on potato dextrose agar at $4{ }^{\circ} \mathrm{C}$ in the Plant Physiology Department, Faculty of Biology, University of Latvia. For the inoculation of the plant material a spore suspension was prepared from a 10-day-old C. arbuscula culture by gently mixing $1 \mathrm{~cm}^{2}$ fungal mycelium fragment in $20 \mathrm{~mL}$ of sterile water. Fungal spores were counted using a haemocytometer in 10 replicates. The $C$. arbuscula spore concentration prior to the inoculation was $3 \times 10^{5}$ spores $\mathrm{mL}^{-1}$.

\section{Rhododendron propagation with leaf-bud cuttings}

In the study two elepidote rhododendron cultivars 'Babites Lavanda' and 'Nova Zembla' were used. The plant material was obtained from the Experimental Rhododendron Breeding Nursery "Babiite", University of Latvia, and 2.5 $\mathrm{cm}$ long leaf-bud cuttings were prepared. Further, three experimental treatments were used. For C. arbuscula treatment, cuttings were immersed in the spore suspension and dipped in talc powder; for indole-3-butyric acid (IBA) treatment cuttings were dipped in 1\% IBA on talc powder. Control cuttings were dipped in talc powder. Cuttings were inserted in plastic trays containing soil mixture of peat moss and pine needles (1:1), covered with a polyethylene tent and maintained in a growth chamber with a $16 \mathrm{~h}$ photoperiod, $23 \pm 2{ }^{\circ} \mathrm{C}$ (day) and $20 \pm 2{ }^{\circ} \mathrm{C}$ (night), under fluorescent lamps (Osram L36 W/77 Fluora; photosynthetic photon flux density $80 \mu \mathrm{mol} \mathrm{m}{ }^{-2} \mathrm{~s}^{-1}$ ). For each treatment four plastic trays with 45 leaf-bud cuttings each were used.

For anatomical study and peroxidase assay plant material (nine cuttings per treatment) was randomly collected daily from Day 1 till Day 5, and every third day afterwards till Day 26.

Two and seven months after the beginning of the experiment rooting and survival (\%) of cuttings were recorded.

\section{Anatomical studies}

Stems of nine cuttings per treatment were fixed in FAA solution $[37 \%$ formaldehyde : $95 \%$ ethanol : acetic acid : distilled water $(10: 50: 5: 35)]$ for anatomical study (Ruzin 1999). After fixation, tissues were dehydrated in an ethanol-tert-butyl alcohol series, and embedded in paraffin Histowax (Histolab Products AB, Sweden; Ruzin 1999). Serial 25 to $30 \mu \mathrm{m}$ thick cross sections at the basal end of cuttings were prepared using a rotary microtome (Leica RM2145 Rotary Microtome, Leica Microsystems Nussloch $\mathrm{GmbH})$. Further cross sections were deparaffinized in a xylene-ethanol series, stained with Astra blue/safranin (Braune et al. 1999), dehydrated in an ethanol-xylene series, and mounted on glass slides in Pertex mounting medium for light microscopy (Histolab Products AB, Sweden). Sections were examined and photographed using a Leica DM5500B light microscope equipped with a digital camera Leica DFC490.

\section{Guaiacol peroxidase assay}

After collection of plant material leaves of nine cuttings avoiding the main vain and damaged leaf parts were cut in smaller pieces, separated in three replicates, $0.5 \mathrm{~g}$ each, and frozen in $-20^{\circ} \mathrm{C}$ for the guaiacol peroxidase assay. Leaves $(0.5 \mathrm{~g})$ were frozen in liquid nitrogen and ground to a fine powder. Enzyme was extracted with $25 \mathrm{mmol} \mathrm{L}^{-1} \mathrm{HEPES}$ /KOH buffer (pH 7.2) containing $1 \mathrm{mmol} \mathrm{L}^{-1}$ EDTA, 3\% $(\mathrm{w} / \mathrm{v})$ polyvinylpolypyrrolidone and $0.8 \%(\mathrm{v} / \mathrm{v})$ Triton $\mathrm{X}-100$ (polyethylene glycol p-(1,1,3,3-tetramethylbutyl)phenyl ether) for $15 \mathrm{~min}$ at $4{ }^{\circ} \mathrm{C}$. The homogenate was centrifuged at $13000 \mathrm{~g}$ for $20 \mathrm{~min}$. For the assay supernatant was used. Peroxidase activity was measured spectrophotometrically with a Camspec M501 Single beam UV/Vis spectrophotometer (Spectronic Camspec) at $470 \mathrm{~nm}$ in a reaction mixture containing $2 \mathrm{~mL} 50 \mathrm{mmol}$ $\mathrm{L}^{-1}$ sodium phosphate buffer ( $\left.\mathrm{pH} 7.0\right)$ with $10 \mathrm{mmol} \mathrm{L}^{-1}$ guaiacol, $0.5 \mathrm{~mL} 30 \mathrm{mmol} \mathrm{L}^{-1} \mathrm{H}_{2} \mathrm{O}_{2}$ and $0.1 \mathrm{~mL}$ enzymatic extract. Reaction mixture without $\mathrm{H}_{2} \mathrm{O}_{2}$ was used as a 
reference (Andersone, Ievinsh, 2002). Enzyme activity was calculated as a change in absorption per minute per $1 \mathrm{~g}$ fresh mass.

\section{Data analysis}

Peroxidase assay data analysis was performed in GraphPad Prism 6 for Windows (version 6.01) software. Data were checked for outliers and normality. The Tukey's test was used for comparison of peroxidase activity data. To compare the effect of treatments on average peroxidase activity during the experiment, the Pearson's correlation coefficient was determined $(\alpha=0.05)$. In graphs, all data are presented as mean \pm standard error.

\section{Results}

\section{Anatomical study}

During anatomical study formation of root initials and root primordia in the phloem region was observed in bases of rhododendron leaf-bud cuttings (Fig. 1 and 2). In rhododendron cv. 'Babites Lavanda' the first root initials were observed on Day 3 in the control and C. arbusculatreated cuttings, while in IBA-treated cuttings the first initial was found on Day 4. The first root primordia were found on Day 17, Day 20 and Day 23 in the control, and C. arbuscula and IBA-treated leaf-bud cuttings, respectively. Two months after the beginning of the experiment, 96, 92 and $94 \%$ of the control, C. arbuscula- and IBA-treated cuttings were rooted, respectively. Seven months later 54,
70 and $73 \%$ of previously rooted control, C. arbuscula and IBA-treated cuttings of cv. 'Babites Lavanda' had survived, respectively.

In rhododendron cv. 'Nova Zembla' the first root initials were found on Day 14, Day 5 and Day 3 in control, and C. arbuscula and IBA-treated leaf-bud cuttings, respectively. In control cuttings development of root primordia was not observed until Day 26, while in C. arbuscula- and IBAtreated cuttings the first root primordia were observed on Day 20 and Day 26, respectively. Two months after the beginning of the experiment, $38 \%$ of control, $63 \%$ of $C$. arbuscula- and $70 \%$ of IBA-treated cuttings were rooted. Information concerning seven-month survival of leaf-bud cuttings for this cultivar was not obtained.

In bases of rhododendron cv. 'Babites Lavanda' leaf-bud cuttings, tracheary nests consisting of tracheary elements were not observed, while in rhododendron cv. 'Nova Zembla' control, C. arbuscula- and IBA-treated cuttings 14, seven and five tracheary nests, respectively, were found in callus during the experiment (Fig. 3). Fungal hyphae were detected on cuticle of $C$. arbuscula-treated rhododendron cv. 'Babītes Lavanda' cuttings on Day 2 (Fig. 4). However, presence of fungal hyphae in tissue of cuttings was not observed during the rest of the experimen, neither in $\mathrm{cv}$. 'Babìtes Lavanda' nor cv. 'Nova Zembla'.

\section{Changes in peroxidase activity}

In general, similar changes in leaf peroxidase activity were evident in control, IBA- and C. arbuscula-treated leaf-

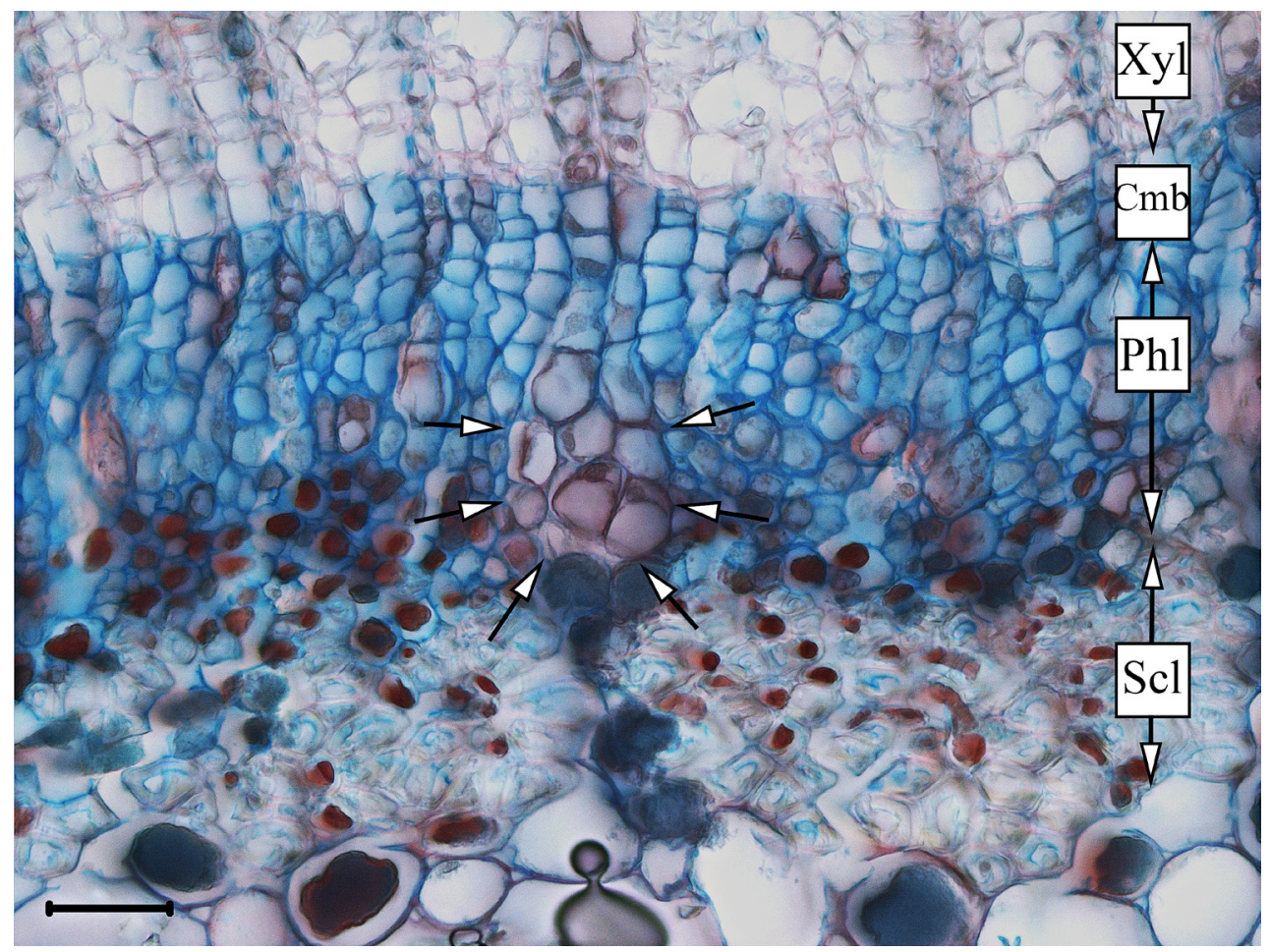

Fig. 1. Adventitious root initial (arrows) in Calcarisporium arbuscula-treated leaf-bud cutting base of rhododendron cv. 'Babītes Lavanda' on Day 3. Xyl, xylem; Cmb, cambium; Phl, phloem; Scl, sclerenchyma. Scale bar: $50 \mu \mathrm{m}$. 


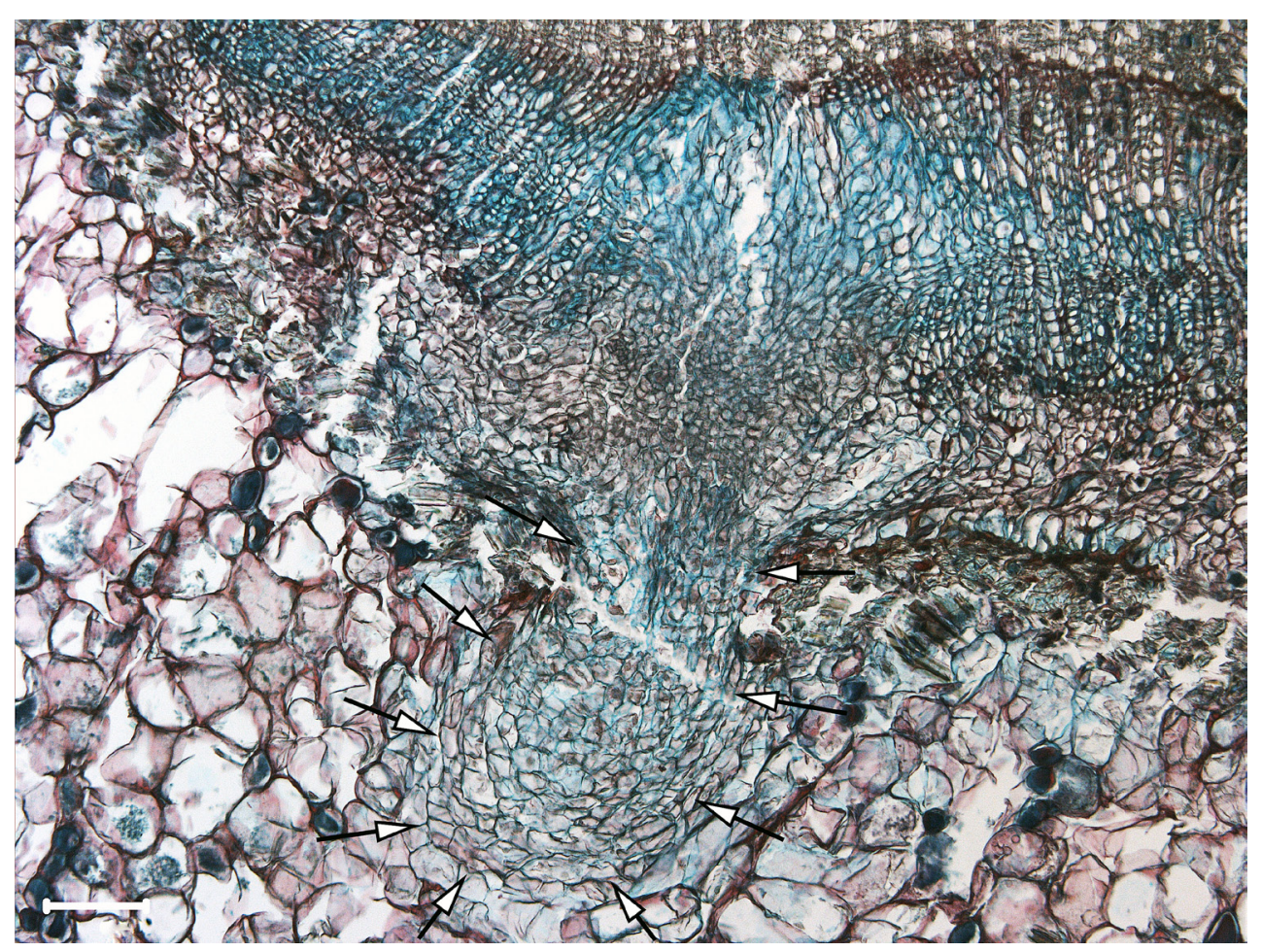

Fig. 2. Adventitious root primordium (arrows) in IBA-treated leaf-bud cutting base of rhododendron cv. 'Babītes Lavanda' on Day 23. Scale bar: $100 \mu \mathrm{m}$.

bud cuttings of rhododendron cv. 'Babites Lavanda' (Fig. 5). There was significant correlation between peroxidase activity in C. arbuscula-treated and control $(p \leq 0.005)$ as well as in control and IBA-treated $(p \leq 0.005)$ rhododendron cv. 'Babìtes Lavanda' leaf-bud cuttings. In both control and IBA-treated cuttings an increase in peroxidase activity was

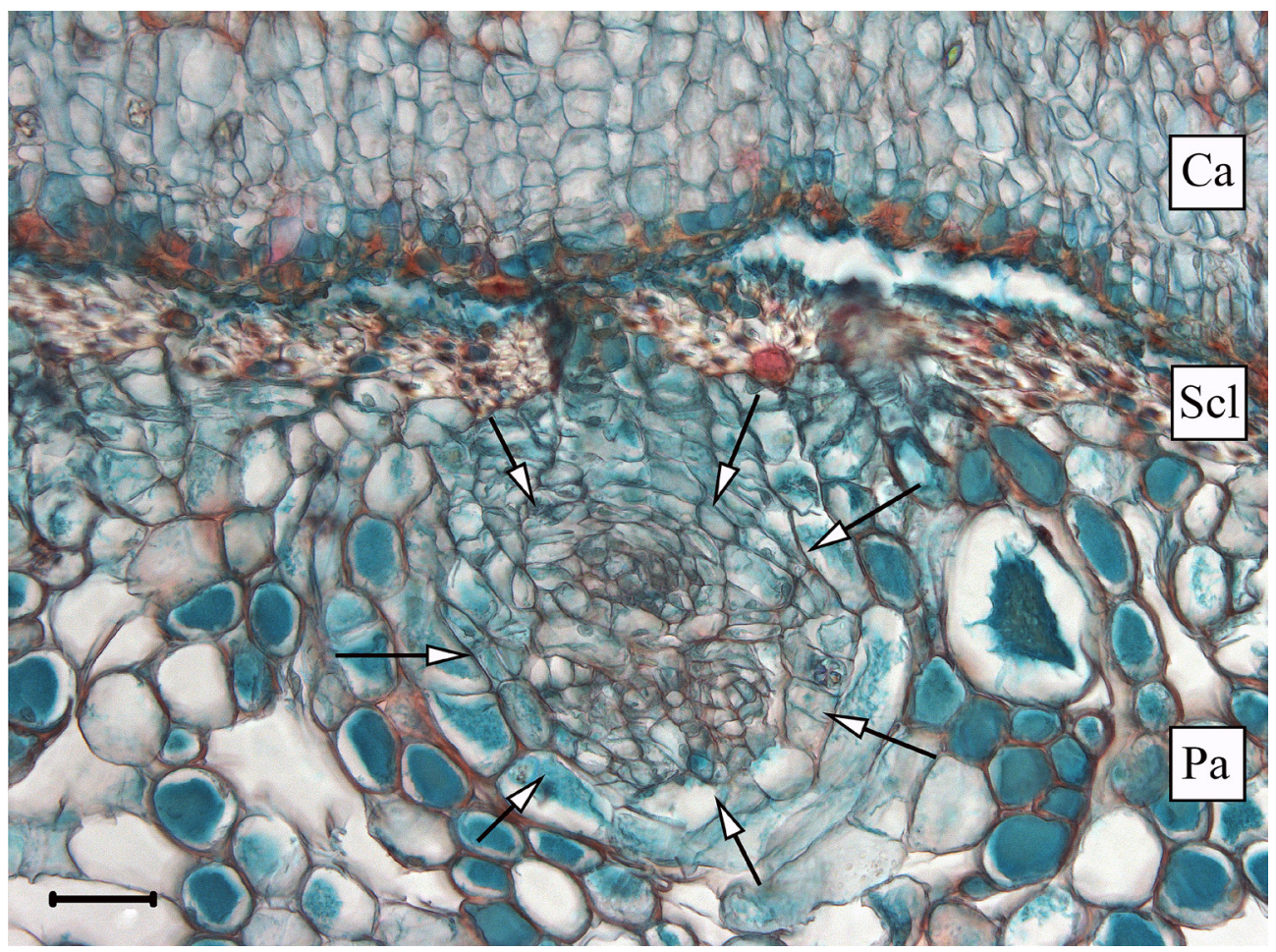

Fig. 3. Tracheary nest (arrows) in base of control leaf-bud cutting of rhododendron cv. 'Nova Zembla' on Day 14. Ca, callus; Scl, sclerenchyma; Pa, parenchyma. Scale bar: $50 \mu \mathrm{m}$. 


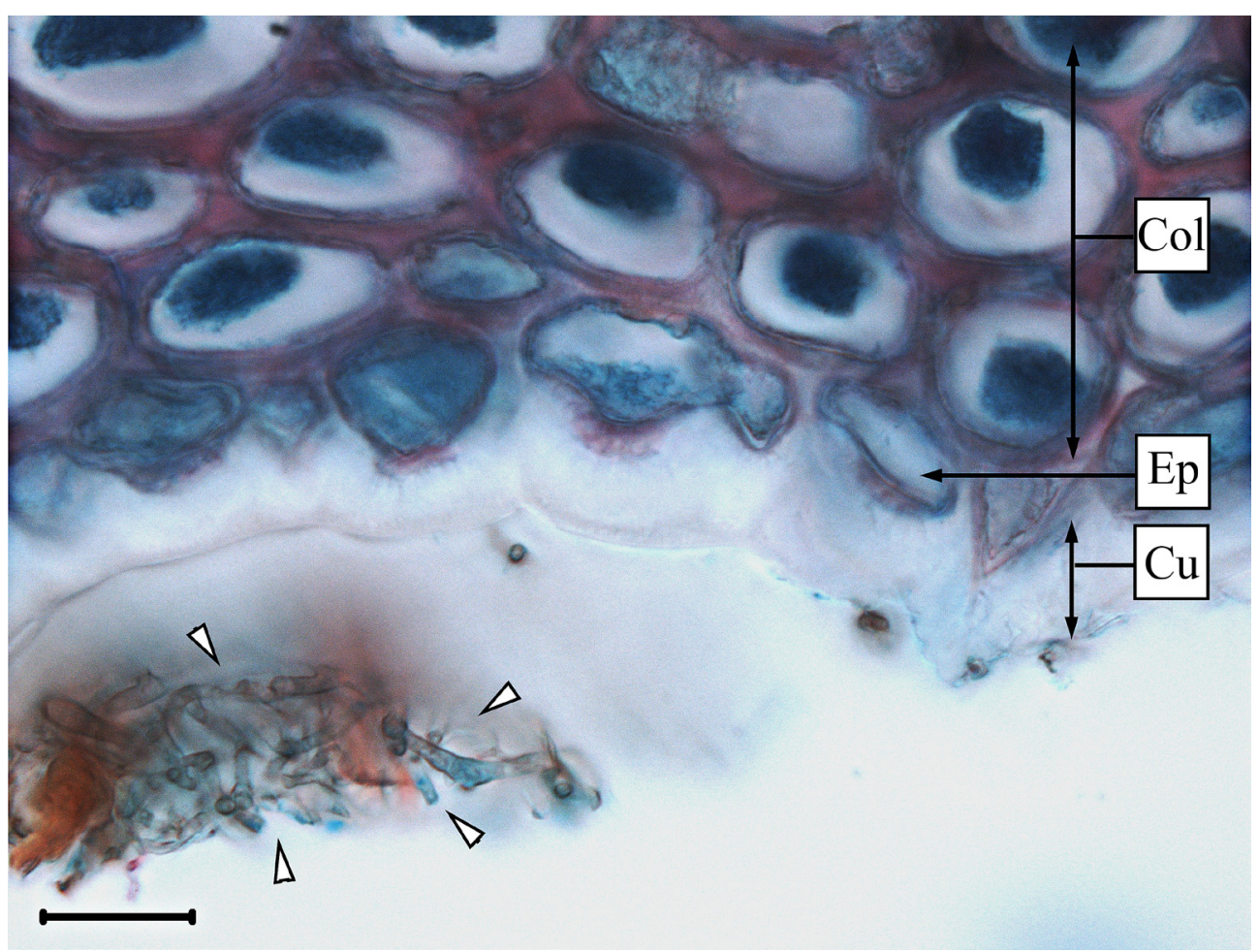

Fig. 4. Fungal hyphae (arrowheads) on cuticle of Calcarisporium arbuscula treated leaf-bud cutting base of rhododendron cv. 'Babites Lavanda' on Day 2. Col, collenchyma; Ep, epidermis; Cu, cuticle. Scale bar: $10 \mu \mathrm{m}$.

observed until Day 2 of the experiment. In control cuttings it was followed by a sharp decline in peroxidase activity until Day 5 and further only non-significant fluctuations until Day 26 were evident. In IBA-treated cuttings the initial increase of peroxidase activity was followed by a sharp decrease until Day 3 and a minor increase until Day 5 , which was followed by a further gradual decrease until Day 26. In C. arbuscula-treated cuttings a sharp decrease in peroxidase activity was observed from Day 1 till Day 5. Further significant changes were not observed until Day 14. From this point till Day 26, fluctuations in peroxidase activity occurred.

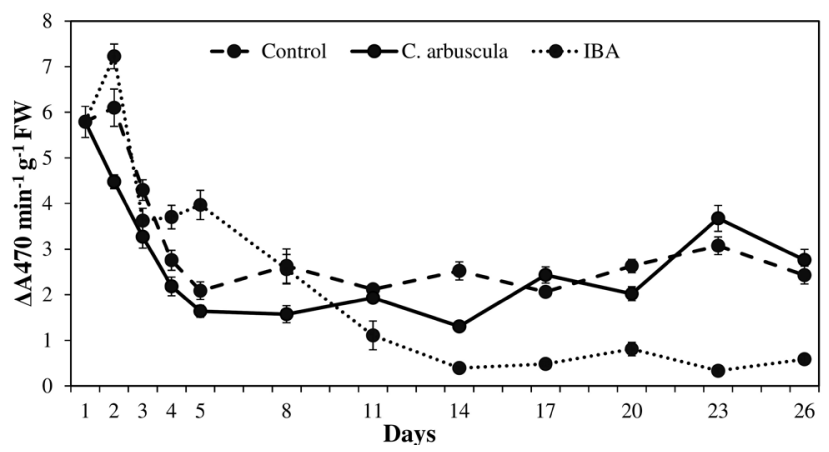

Fig. 5. Changes in peroxidase activity in leaves of control, IBAand Calcarisporium arbuscula-treated leaf-bud cuttings of rhododendron 'Babītes Lavanda' during the rhizogenesis. Values $( \pm$ SE) are means of three determinations from three independent measurements for each date.
There was significant correlation between peroxidase activity in C. arbuscula- and IBA-treated $(p \leq 0.05)$ as well as control and IBA-treated $(p \leq 0.05)$ leaf-bud cuttings of rhododendron cv. 'Nova Zembla'. In control cuttings, there was an increase in peroxidase activity until Day 2, which was followed by decrease until Day 5 and insignificant fluctuations until Day 26. In IBA and C. arbuscula-treated cuttings initially there was a sharp increase in peroxidase activity until Day 3 and Day 4, respectively. The increase was followed by decline until Day 8 , for both treatments. Further, fluctuations until Day 20 were observed for peroxidase activity of IBA-treated cuttings. From Day 20

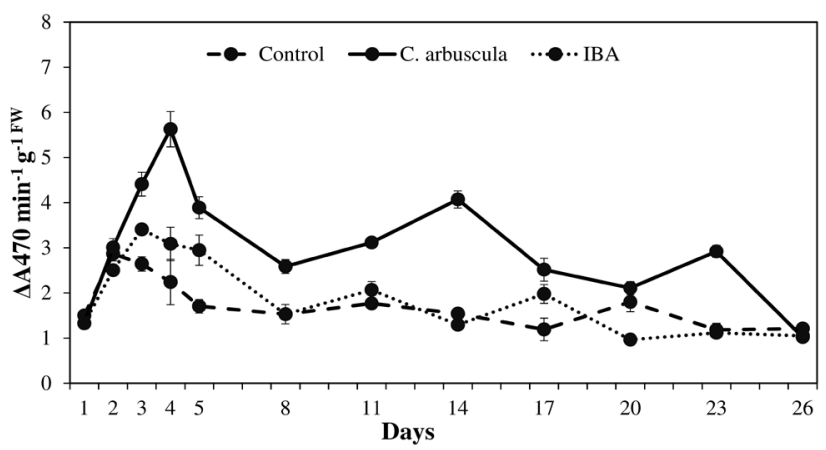

Fig. 6. Changes in peroxidase activity in leaves of control, IBAand Calcarisporium arbuscula-treated leaf-bud cuttings of rhododendron cv. 'Nova Zembla' during the rhizogenesis. Values $( \pm$ SE) are means of three determinations from three independent measurements for each date. 
until Day 26 no significant differences were detected. In C. arbuscula-treated cuttings an increase in peroxidase activity was observed from Day 8 until Day 14. In addition, there was a decrease from Day 14 until Day 20 followed by a small increase in Day 23 and a further decrease in Day 26. While peroxidase activity in control and IBA-treated cuttings was at similar level during the experiment, in $C$. arbuscula-treated cuttings it was significantly higher $(p \leq$ 0.05).

\section{Discussion}

Both from anatomical and biochemical points of view, adventitious root formation is a complex multistage process, which can be divided into induction, initiation and expression phases (Gaspar et al. 1994). During the induction phase a decrease in peroxidase activity can be observed, while there are no evident anatomical changes. This is followed by an initiation phase characterized by an increase of peroxidase activity with a maximum level at the end of the phase, together with microscopically visible root initials. During the expression phase when root primordia develop and grow, peroxidase activity gradually decreases (Gaspar et al. 1994). Timing of these phases may differ depending on the taxon and propagation technique used. In some studies increase in peroxidase activity followed by a decrease was detected only in initiation and expression phases, while decrease in peroxidase activity characterizing induction phase was not observed (Husen 2008; Kose et al. 2011; Molassiotis et al. 2004; San-José et al. 1992; Saxena et al. 2000; Zhang et al. 2017). This could be due to insufficiently frequent sampling of plant material and thus missed induction phase. In other studies, although the cuttings developed roots, biochemical adventitious rooting phases in respect to changes in peroxidase activity were not detected at all, for example, in Berberis buxifolia microshoots (Arena et al. 2003), easy- and difficult-toroot Grevillea species microshoots (Ludwig-Müller 2003) and evergreen azalea microshoots (Elmongy et al. 2018). Similarly, in the present study, it was not possible to detect biochemical rooting phases in rhododendron $\mathrm{cv}$. 'Babītes Lavanda' control and C. arbuscula-treated leaf-bud cuttings as well as in all treatments in rhododendron $\mathrm{cv}$. 'Nova Zembla' cuttings (Fig. 5 and 6). Lack of appearance of a typical biochemical rooting phases in control leafbud cuttings of rhododendron cv. 'Nova Zembla' might be explained by the rather low rooting ability of the cultivar. This is confirmed by late development of first initial and lower rooting percentage in control cuttings in comparison to other treatments. Observation of early initial development coinciding with the maximum peroxidase activity in IBA-treated cuttings of cv. 'Nova Zembla' on Day 3 suggests that the induction phase in this treatment might be indeed missed. A short induction phase lasting for only a few hours has been reported in several woody plant species during rooting in vitro or ex vitro (Caboni et al 1997; Gonçalves et al. 1998; Naija et al. 2008). Biochemical phases of rooting indicated by changes in peroxidase activity do not always correspond with anatomical observations. Syros et al. (2004) in a rooting genotype of Ebenus cretica treated with IBA found development of root primordia at the end of the biochemical initiation phase. In Cotinus coggyria microshoots during in vitro rooting primordia were observed during the biochemical induction phase (Ilczuk, Jacygrad 2016). In the current study the only treatment with simultaneously occurring anatomical and biochemical rooting phases was in the IBA treatment for cuttings of rhododendron cv. 'Babìtes Lavanda.' In this treatment, the induction phase with decrease in peroxidase activity occurred from Day 2 till Day 3, and the initiation phase with increase in peroxidase activity and formation of first root initials from Day 3 till Day 5, which was followed by a gradual decrease in peroxidase activity and formation of root primordia. In leaf-bud cuttings of rhododendron cv. 'Babites Lavanda', noteworthy differences in adventitious root formation were not observed between treatments, neither anatomically nor biochemically. Cuttings of all treatments rooted equally well. However, in the long term, the best survival percentage was reached with IBA and C. arbuscula treatments, leading to 73 and $70 \%$ survival of previously rooted cuttings, respectively. This might be explained by the positive effect of IBA on root system size of evergreen rhododendron cuttings, as previously reported by Nawrocka-Grześkowiak (2004).

In contrast, in leaf-bud cuttings of rhododendron cv. 'Nova Zembla' the best results with faster root initial and primordia formation and highest rooting percentage were obtained in treatments with IBA and C. arbuscula. Interestingly, in this cultivar, tracheary nests were observed and higher number of them was detected in control cuttings. Tracheary nest formation in microcuttings of Ceratonia siliqua has been shown to compete with the adventitious root formation in absence of exogenously applied auxin, which suggests that if the auxin level is insufficient, cuttings undergo a xylogenesis program instead of rhizogenesis (Ricci et al. 2016). It has been observed that wound tissue forming cuttings of Pinus sylvestris in vitro grow equally well as rooting cuttings; and presence of vascular connections between tracheary nests and vascular system of cuttings suggests that tracheary nests may function in nutrient and water uptake (Grönroos, von Arnold 1985). In our study, tracheary nests were not observed in rhododendron cv. 'Babites Lavanda' cuttings that rooted well, while they were present in rhododendron cv. 'Nova Zembla' cuttings, especially in control conditions, which had the worst rooting percentage. According to observations of Grönroos and von Arnold (1985), Ricci et al. (2016) and the present results, it is possible that in plants with rooting difficulties tracheary nests might function as water- and nutrient-absorbing structures and as a conducting system, 
probably due to lower response to auxin stimulus or lower accumulation of auxin in basal parts of cuttings.

Druege et al. (2007) showed that inoculation of rooting substrate with a fungal root endophyte Piriformospora indica promoted adventitious root development in poinsettia and pelargonium cuttings. It was suggested that the effect of $P$. indica might be explained by induction of changes in auxin, ethylene and probably polyamine levels in plants. It is well known that adventitious root formation process relies on many factors, both exogeneous and endogenous by nature, but the key players are plant hormones (de Klerk et al. 1999). Similarly, we have previously shown that $C$. arbuscula has a positive effect on ex vitro rooting of rhododendron $\mathrm{cv}$. 'Babītes Lavanda' and cv. 'Nova Zembla' microcuttings and suggested a similar promoting mechanism (Dokane et al. 2017).

Plant and fungal pathogen or endophyte interactions initially are physiologically similar, as they begin with recognition of chitin and its oligomers by plant receptors and initial triggering of plant defence mechanisms (Presti et al. 2015; Zeilinger et al. 2015). During an infection, plant class III peroxidases are known to be involved in lignification and suberization processes as well as in production of reactive oxygen and nitrogen species. Also, it is known that peroxidases are involved in catalysis of antimicrobial metabolite synthesis during infection (Almagro et al. 2009). Thus, during infection, increase in peroxidase activity could be expected. Such observations were made in rooted cuttings of Dianthus caryophyllus resistant to Fusarium oxysporum f. sp. dianthi and treated with $F$. oxysporum, while in susceptible $D$. caryophyllus cuttings significant changes in guaiacol peroxidase activity were not detected (Ardila et al.2014). During establishment of plantendophyte associations, changes in activity of peroxidase has not been studied previously. In the present study, peroxidase activity was significantly higher in C. arbusculatreated cuttings of rhododendron cv. 'Nova Zembla' during the whole experiment, while in cv. 'Babites Lavanda' peroxidase activity did not significantly differ between the treatments. This difference might be explained by the fact that $\mathrm{cv}$. 'Babites Lavanda' is a host plant of this fungus and both cultivars have different physiological reactions to the inoculation, 'Nova Zembla' being slower in establishment of an association. Also, the fast response of cv. 'Nova Zembla' cuttings and absence of fungal structures in cutting tissues together with enhanced rooting of this treatment suggest the presence of some biologically active compounds in fungal suspension. This might be caused either by fungal proteins or by plant hormone-like compounds.

Similarly, as in our previous study on the effect of $C$. arbuscula on in vitro growth and ex vitro adventitious rooting of microcuttings of the same rhododendron cultivars (Dokane et al.2017), in present study the effect of fungus was more pronounced in cuttings of rhododendron cultivar 'Nova Zembla' than in cultivar 'Babìtes Lavanda', showing both faster root initial development and higher rooting percentage in comparison to control cuttings. $C$. arbuscula treatment had positive effect in the long term in cuttings of cv. 'Babites Lavanda', showing increased survival percentage of rooted cuttings. According to these results, C. arbuscula has a potential for use in rhododendron propagation by cuttings.

\section{Acknowledgements}

Authors are thankful to colleagues of the Microbial Strain Collection of Latvia. This work has been supported by the European Social Fund within the project «Support for Doctoral Studies at University of Latvia» No. 2009/0138/1DP/1.1.2.1.2/09/ IPIA/VIAA/004.

\section{References}

Almagro L., Gómez Ros L.V., Belchi-Navarro S., Bru R., Ros Barceló A., Pedreno M.A. 2008. Class III peroxidases in plant defence reactions. J. Exp. Bot. 60: 377-390.

Andersone U., Ievinsh G. 2002. Changes of morphogenic competence in mature Pinus sylvestris L. buds in vitro. Ann. Bot. 90: 293-298.

Ardila H.D., Torres A.M., Martínez S.T., Higuera B.L. 2014. Biochemical and molecular evidence for the role of class III peroxidases in the resistance of carnation (Dianthus caryophyllus L.) to Fusarium oxysporum f. sp. dianthi. Physiol. Mol. Plant Path. 85: 42-52.

Arena M.E., Pastur G.M., Benavides M.P., Zappacosta D., Eliasco E., Curvetto N. 2003. Peroxidase and polyamine activity variation during the in vitro rooting of Berberis buxifolia. New Zeal. J. Bot. 41: 475-485.

Ávila Díaz-Granados R.A., Orozco Silva O.J., Moreno G.L., Magnitskiy S., Rodríguez A. 2009. Influence of mycorrhizal fungi on the rooting of stem and stolon cuttings of the Colombian blueberry (Vaccinium meridionale Swartz). Int. J. Fruit Sci. 9: 372-384.

Bizabani C., Dames J. 2015. Effects of inoculating Lachnum and Cadophora isolates on the growth of Vaccinium corymbosum. Microbiol. Res. 181: 68-74.

Braune W., Leman A., Taubert H. 1999. Pflanzenanatomisches Praktikum I. Spektrum Akademischer Verlag Heidelberg, Berlin.

Caboni E., Tonelli M.G., Lauti P., Iacovacci P., Kevers C., Damiano C., Gaspar T. 1997. Biochemical aspects of almond microcuttings related to in vitro rooting ability. Biol. Plant. 39: 91-97.

De Klerk G.-J., van der Krieken W., de Jong J.-C. 1999. Review. The formation of adventitious roots: new concepts, new possibilities. In Vitro Cell. Dev. Biol. Plant 35: 189-199.

Dokane K., Lazdane M., Kondratovics U. 2012. Endophytic fungi in roots of elepidote rhododendron. Abstract Book of Scandinavian Plant Physiology Society $7^{\text {th }} \mathrm{PhD}$ Student Conference, p. 45.

Dokane K., Megre D., Lazdane M., Kondratovics U. 2014. Does shoot anatomical heterogeneity influence ex vitro adventitious root formation in rhododendron microcuttings? Propag. Ornam. Plants 14: 171-176.

Dokane K., Megre D., Lazdane M., Kondratovics U. 2017. Influence 
of the Calcarisporium arbuscula Preuss on in vitro growth and ex vitro adventitious rooting of two elepidote rhododendron cultivars. Propag. Ornam. Plants 17: 39-47.

Druege U., Baltruschat H., Franken P. 2007. Piriformospora indica promotes adventitious root formation in cuttings. Sci. Hortic. 112: 422-426.

Elmongy M.S., Zhou H., Cao Y., Liu B., Xia Y. 2018. The effect of humic acid on endogenous hormone levels and antioxidant enzyme activity during in vitro rooting of evergreen azalea. Sci. Hort. 227: 234-243.

Ferus P., Konôpková J., Bošiaková D., Hotka P. 2017. Effective rhododendron propagation through stem cuttings. J. Appl. Hortic. 19: 226-229.

Fusconi A., Trotta A., Dho S., Camusso W., Mucciarelli M. 2010. In vitro interactions between Mentha piperita $\mathrm{L}$. and a non-mycorrhizal endophyte: root morphogenesis, fungus development and nutritional relationships. J. Plant Interact. 5: 179-188.

Gaspar T., Kevers C., Hausman J.F., Ripetti V. 1994. Peroxidase activity and endogenous free auxin during adventitious root formation. In: Lumsden P.J., Nicholas L.R., Davies W.J. (eds) Physiology, Growth and Development of Plants in Culture. Kluwer Academic Publishers, Dordrecht. pp. 289-298.

Gonçalves J.C., Diogo G., Amâncio S. 1998. In vitro propagation of chestnut (Castanea sativa X C. crenata): Effects of rooting treatments on plant survival, peroxidase activity and anatomical changes during adventitious root formation. Sci. Hortic. 72: 265-275.

Grelet G.A., Ba R., Goeke D.F., Houliston G.J., Taylor A.F., Durall D.M. 2017. A plant growth-promoting symbiosis between Mycena galopus and Vaccinium corymbosum seedlings. Mycorrhiza 27: 831-839.

Grönroos A., von Arnold S. 1985. Initiation and development of wound tissue and roots on hypocotyl cuttings of Pinus sylvestris in vitro. Physiol. Plant. 64: 393-401.

Hartmann H.T., Kester D.E., Davies F.T., Geneve R.L. 2014. Hartmann \& Kester's Plant Propagation: Principles and Practices. $8^{\text {th }}$ Ed. Harlow - Pearson Education Limited. 915 p.

Husen A. 2008. Clonal propagation of Dalbergia sissoo Roxb. and associated metabolic changes during adventitious root primordium development. New For. 36: 13-27.

Ilczuk A., Jacygrad E. 2016. The effect of IBA on anatomical changes and antioxidant enzyme activity during the in vitro rooting of smoke tree (Cotinus coggygria Scop.). Sci. Hortic. 210: 268-276.

Kose C., Erdal S., Kaya O., Atici O. 2011. Comparative evaluation of oxidative enzyme activities during adventitious rooting in the cuttings of grapevine rootstocks. J. Sci. Food Agric. 91: 738-741.

Ludwig-Müller J. 2003. Peroxidase isoenzymes as markers for the rooting ability of easy-to-root and difficult-to-root Grevillea species and cultivars of Protea obstusifolia (Proteaceae). In Vitro Cell. Dev. Biol. Plant 39: 377-383.

Megre D., Dokane K., Kondratovics U. 2011. Can changes in starch content and peroxidase activity be used as rooting phase markers for rhododendron leaf bud cuttings? Acta Biol.
Cracov. Ser. Bot. 53: 74-79.

Metaxas D.J., Syros T.D., Yupsanis T., Economou A.S. 2004. Peroxidases during adventitious rooting in cuttings of Arbutus unedo and Taxus baccata as affected by plant genotype and growth regulator treatment. Plant Growth Reg. 44: 257-266.

Molassiotis A.N., Dimassi K., Diamantidis G., Therios I. 2004. Changes in peroxidases and catalase activity during in vitro rooting. Biol. Plant. 48: 1-5.

Mucciarelli M., Scannerini S., Bertea C., Maffei M. 2003. In vitro and in vivo peppermint (Mentha piperita) growth promotion by nonmycorrhizal fungal colonization. New Phytol. 158: 579-591.

Naija S., Elloumi N., Jbir N., Ammar S., Kevers C. 2008. Anatomical and biochemical changes during adventitious rooting of apple rootstocks MM 106 cultured in vitro. C. R. Biol. 331: 518-525.

Nawrocka-Grześkowiak U. 2004. Effect of growth substances on the rooting of cuttings of rhododendron species. Folia Hortic. 16: 115-123.

Presti L., Lanver D., Schweizer G., Tanaka S., Liang L., Tollot M., Kahmann R. 2015. Fungal effectors and plant susceptibility. Annu. Rev. Plant Biol. 66: 513-545.

Ricci A., Rolli E., Brunoni F., Dramis L., Sacco E., Fattorini L., Ruffoni B., Díaz-Sala C., Altamura M.M. 2016.1,3-di(benzo[d] oxazol-5-yl)urea acts as either adventitious rooting adjuvant or xylogenesis enhancer in carob and pine microcuttings depending on the presence/absence of exogenous indole-3butyric acid. Plant Cell Tissue Organ Cult. 126: 411-427.

Ruzin S.E. 1999. Plant Microtechnique and Microscopy. Oxford University Press, New York. 322 p.

San-José M.C., Vidal N., Ballester A. 1992. Anatomical and biochemical changes during root formation in oak and apple shoots cultured in vitro. Agronomie 12: 767-774.

Saxena C., Samantaray S., Rout G.R., Das P. 2000. Effect of auxins on in vitro rooting of Plumbago zeylanica: peroxidase activity as a marker for root induction. Biol. Plant. 43: 121-124.

Scagel C.F. 2005. Isolate-specific rooting responses of Leucothoe fontanesiana cuttings to inoculation with ericoid mycorrhizal fungi. J. Hortic. Sci. Biotechnol. 80: 254-262.

Syros T., Yupsanis T., Zafiriadis H., Economou A. 2004. Activity and isoforms of peroxidases, lignin and anatomy, during adventitious rooting in cuttings of Ebenus cretica L. J. Plant Physiol. 161: 69-77.

Wells J.S. 1982. The propagation of hybrid rhododendrons from stem cuttings - an historical review. J. Am. Rhod. Soc. 36(4).

Yang B., Wang X.M., Ma H.Y., Jia Y., Li X., Dai C.C. 2014. Effects of the fungal endophyte Phomopsis liquidambari on nitrogen uptake and metabolism in rice. Plant Growth Reg. 73: 165-179.

Zeilinger S., Gupta V.K., Dahms T.E., Silva R.N., Singh H.B., Upadhyay R.S., Gomes E.V., Tsui C.K., Nayak S.C. 2015. Friends or foes? Emerging insights from fungal interactions with plants. FEMS Microbiol. Rev. 40: 182-207.

Zhang W., Fan J., Tan Q., Zhao M., Zhou T., Cao F. 2017. The effects of exogenous hormones on rooting process and the activities of key enzymes of Malus hupehensis stem cuttings. PloS One 12: $\mathrm{e} 0172320$. 